\title{
PENGARUH KEPEMIMPINAN TRANSFORMASIONAL DAN KOMITMEN ORGANISASIONAL TERHADAP KEPUASAN KERJA BADAN PEMBERDAYAAN MASYARAKAT DAN PEMDES DENPASAR
}

\author{
Ni Kadek Yustina Novita Sari ${ }^{1}$ \\ I Gusti Ayu Dewi Adnyani²
}

\author{
${ }^{1,2}$ Fakultas Ekonomi dan Bisnis Universitas Udayana, Bali, Indonesia \\ e-mail: vieyustina@yahoo.co.id
}

\begin{abstract}
ABSTRAK
Perusahaan akan memiliki cara untuk meningkatkan kepuasan kerja karyawan. Faktor yang dapat meningkatkannya adalah kepemimpinan transformasional dan komitmen organisasional karyawan. Tujuan penelitian ini adalah untuk menguji pengaruh kepemimpinan transformasional dan komitmen organisasional terhadap kepuasan kerja pegawai pada Badan Pemberdayaan Masyarakat dan Pemdes Pemerintah Kota Denpasar. Populasi penelitian ini adalah seluruh pegawai Badan Pemberdayaan Masyarakat dan Pemdes Pemerintah Kota Denpasar yang berjumlah 34 orang. Teknik penentuan sampel yang digunakan adalah sampling jenuh, maka seluruh populasi dijadikan responden dalam penelitian. Data di analisis menggunakan teknik analisis regresi linier berganda. Hasil penelitian menunjukkan bahwa kepemimpinan transformasional dan komitmen organisasional secara parsial berpengaruh positif dan signifikan terhadap kepuasan kerja pegawai pada Badan Pemberdayaan Masyarakat dan Pemdes Pemerintah Kota Denpasar. Hal ini memiliki makna bahwa semakin baik penerapan gaya kepemimpinan, dan semakin tinggi komitmen organisasional yang dimiliki pegawai, maka semakin bertambah pula tingkat kepuasan kerja pegawai pada Badan Pemberdayaan Masyarakat dan Pemdes Pemerintah Kota Denpasar.
\end{abstract}

Kata Kunci: kepemimpinan transformasional, komitmen organisasional, kepuasan kerja

\begin{abstract}
Companies in general will have all sorts of ways to improve employee job satisfaction. Factors that can improve employee job satisfaction are transformational leadership and organizational commitment of employees. The purpose of this study was to examine the effect of transformational leadership and organizational commitment on employee job satisfaction at Community Empowerment Board and Pemdes Government of Denpasar City. The population of this research is all employees of Community Empowerment Board and Pemdes Government of Denpasar City which amounted to 34 people, with sample determination technique used is saturated or census sampling, hence all member of population become respondent in research. Data were analyzed using multiple linear regression analysis technique. The results showed that transformational leadership and organizational commitment partially have a positive and significant effect on employee job satisfaction at Community Empowerment Board and Pemdes Government of Denpasar City. This has the meaning that the better the application of leadership style, and the higher organizational commitment that employees have, the more the level of employee job satisfaction at the Community Empowerment Board and Pemdes Government of Denpasar City.

Keywords: transformational leadership, organizational commitment, job satisfaction
\end{abstract}




\section{PENDAHULUAN}

Berhadapan dengan usaha peningkatan kinerja karyawan, salah satu permasalahan dasar adalah bagaimana sebenarnya meningkatkan kepuasan kerja karyawan. Locke dalam Marcelius (2004: 48) mendefinisikan kepuasan kerja sebagai emosi positif atau perasaan senang, sebagai hasil dari penilaian seorang karyawan terhadap faktor pekerjaan atau pengalaman-pengalaman kerjanya. Hasibuan (2008 : 202) menyatakan bahwa kepuasan kerja adalah sikap emosional yang menyenangkan dan mencintai pekerjaannya. Sikap ini dicerminkan oleh moral kerja, kedisiplinan dan prestasi kerja. Kepuasan kerja dinikmati dalam pekerjaan, luar pekerjaan dan kombinasi dalam dan luar pekerjaan. Fenomena ketidakpuasan dalam bekerja menjadi masalah serius yang dihadapi oleh perusahaan.

Ketidakpuasan terjadi karena kondisi kerja yang dianggap tidak sesuai dengan harapan karyawan, ketika ketidakpuasan terjadi maka stabilitas dan keberhasilan organisasi akan terhambat. Raharjo (2006) menyatakan bahwa salah satu faktor kepuasan kerja meliputi pekerjaan yang menarik/menantang, kesempatan berprestasi, memperoleh penghargaan dan promosi, terpenuhinya faktor tersebut akan menimbulkan kepuasan namun tidak terpenuhinya faktor ini tidak selalu mengakibatkan ketidakpuasan, sedangkan dissatisfies (hygiene factors) adalah faktor-faktor yang menjadi sumber ketidakpuasan yang meliputi gaji/upah, pengawasan, hubungan antar pribadi serta kondisi kerja dan status.

Menurut Purnomo (2010) menyatakan bahwa salah satu penyebab ketidakpuasan yaitu kurang adanya penerapan kepemimpinan tranformasional di 
Ni Kadek Yustina Novita Sari, Pengaruh Kepemimpinan Transformasional dan...

perusahaan tersebut. Kepemimpinan transformasional merupakan kepemimpinan yang berusaha untuk mengubah perilaku bawahan agar memiliki kemampuan dan motivasi tinggi, serta berupaya mencapai prestasi kerja yang tinggi dan bermutu untuk mencapai tujuan bersama (Munandar, 2001). Kepemimpinan transformasional akan membuat para pengikut merasakan kepercayaan, kekaguman, kesetiaan dan penghormatan terhadap pemimpin, dan mereka termotivasi untuk melakukan lebih dari pada yang awalnya diharapkan dari mereka (Yulk, 2010).

Penelitian ini dilakukan dengan mewawancarai lima orang karyawan tetap Badan Pemberdayaan Masyarakat dan Pemdes Pemerintah Kota Denpasar yang tidak memiliki rasa puas terhadap perusahaan. Karyawan pertama bernama Andi (nama asli disamarkan) dalam wawancara mempunyai keluhan terkait distribusi yang tidak adil dengan menyatakan bahwa "ketidaksesuaian antara beban kerja dengan insentif yang didapat". Karyawan kedua bernama Ayu (nama asli disamarkan) dalam wawancara menyatakan bahwa "ketidaksesuaian imbalan dengan jabatan yang sama diperusahaan lain”. Karyawan ketiga bernama Ani (nama asli disamarkan) dan karyawan keempat bernama Joni (nama asli disamarkan) menyatakan bahwa "ketidaksesuaian jabatan kerja dengan keahliannya dan kurangnya motivasi serta dukungan dari atasan". Karyawan kelima bernama Gendis (nama asli disamarkan) menyatakan bahwa "jam kerja melewati batas waktu yang ditentukan".

Hasil wawancara mengungkapkan bahwa kelima karyawan merasakan kurangnya kepuasan dalam pemberian yang berkaitan dengan insentif yang tidak 
sesuai dengan beban kerja yang didapatkan karyawan. Kekecewaan karyawan terhadap penerapan kebijakan-kebijakan perusahaan mengenai imbalan, penghargaan dan promosi. Kebijakan yang ditetapkan oleh perusahaan beserta praktiknya secara langsung mempengaruhi perilaku individu dalam bekerja dan karyawan akan mempunyai penilaian atau pandangan yang berbeda terhadap suatu kebijakan serta praktik MSDM di perusahan. Kekecewaan yang dirasakan karyawan dapat menimbulkan kepuasan kerja yang rendah dengan menunjukan cici-ciri seperti: karyawan selalu terlambat untuk bekerja, ketidakhadiran karyawan untuk bekerja meningkat, komitmen karyawan terhadap organisasi rendah, produktivitas menurun. Bahasan yang terkait dengan kurangnya kepuasan dalam suatu perusahaan yaitu mengenai kepemimpinan transformasional.

Menurut Bass dkk. (1999) kepemimpinan transformasional merupakan persepsi karyawan berdasarkan atas motivasi dan semangat yang diberikan pemimpin terhadap pengikutnya serta mendorong mereka untuk berkinerja tinggi. Pemimpin transformasional adalah pemimpin yang afektif karena dapat meningkatkan kepuasan kerja, komitmen organisasional dan produktivitas bawahan ((Erkutlu, 2008), (Farahani et al., 2011), (Khan et al., 2013)). Kurangnya kepuasan kerja karyawan disebabkan oleh kurang adanya sifat keterbukaan dan rangsangan motivasi dari pimpinan kepada bawahan untuk lebih kreatif dan inovatif dalam menghadapi masalah yang ada pada perusahaan. (Sabir et al., 2011) juga menyatakan kepuasan kerja dipengaruhi oleh gaya kepemimpinan Hal ini sesuai dengan yang dikemukakan oleh (S. Nguni et al., 2006) menyatakan adanya pengaruh kepemimpinan transformasional terhadap 
Ni Kadek Yustina Novita Sari, Pengaruh Kepemimpinan Transformasional dan...

kepuasan kerja karyawan, dimana semakin tinggi tingkat trnasformasional yang di alami maka semakin tinggi jumlah kepuasan keryawan. Wood (2007) mengatakan bahwa kepemimpinan berpengaruh terhadap kepuasan kerja karyawan dimana kecocokan antara gaya kepemimpinan dengan kerja tim akan mempengaruhi tinggi rendahnya kinerja tim.

Bushra (2008) menyatakan organisasi perusahaan sangatlah penting bagi pimpinan untuk bisa memotivasi karyawan guna meningkatkan produktivitas kinerjanya sehingga membuat karyawan bekerja dengan puas dan akan meningkatkan komitmen karyawan. Komitmen organisasi dipengaruhi oleh kepemimpinan transformasional karena pemimpin yang menerapkan kepemimpinan transformasional mampu mengartikulasikan visi, dan memberikan dukungan kepada individu di organisasi (Thamrin, 2012).

Hasil wawancara juga mengungkapkan bahwa, kelima karyawan merasakan kepuasan kerja rendah karena karyawan mengeluhkan imbalan yang diterima tidak sesuai dengan beban kerja yang diberikan serta kurang adanya motivasi atau dukungan dari pimpinan sehingga produktivitas kerja karyawan menurun dan komitmen karyawan menjadi rendah. Sejalan dengan temuan Permatasari (2013), ketika karyawan merasakan kepuasan kerja yang rendah, maka menyebabkan komitmen dan loyalitas karyawan menurun. Pernyataan tersebut, terindikasi bahwa rasa kepuasan karyawan rendah sehingga menimbulkan komitmen yang rendah pula. Hal ini sejalan dengan penelitian yang dilakukan oleh Rohman (2009) menyatakan adanya pengaruh komitmen organisasional terhadap kepuasan kerja. 
Selain itu, hasil wawancara mengungkapkan bahwa kelima karyawan memiliki komitmen yang rendah dengan membandingkan imbalan, tunjangan serta jabatan yang diterima di Kantor Pemberdayaan Masyarakat dan Pemdes Pemerintah Kota Denpasar. Rendahnya komitmen mencerminkan kurangnya tanggung jawab seseorang dalam menjalankan tugasnya. Komitmen menjadi semakain sulit untuk diaplikasikan mengingat rendahnya imbalan yang diberikan karyawan yang tidak sebanding dengan beban kerja yang diberikan. Menurut Rohman (2009) dan Tranggono dan Andi Kartika (2008) menyatakan adanya hubungan yang positif dan signifikan antara komitmen organisasi dengan kepuasan kerja. Wahyono (2005) menyatakan komitmen organisasional merupakan "perspektif yang bersifat keperilakuan dimana komitmen diartikan sebagai perilaku yang konsisten dengan aktifitas (consistent lines of activity)",sehingga semakin tinggi komitmen karyawan terhadap organisasi dapat meningkatkan rasa puas dari karyawan tersebut. Rzwan (2010) mendukung bahwa semakin tinggi komitmen seseorang terhadap organisasi dapat meningkatkan rasa puas yang akan dihasilkan pada diri karyawan. Tahira et al. (2005) menyatakan bahwa sifat dari komitmen organisasional dapat berubah sepanjang waktu, karyawan pekerjaannya cenderung lebih bervariasi dan memiliki kebebasan dalam melakukan penilaian. Karyawan cenderung mengalami kebosanan karena pekerjaannya kurang menantang sehingga hal ini juga menyebabkan komitmen karyawan tersebut akan rendah

Perusahaan pada umumnya akan memiliki segala macam cara untuk meningkatkan kepuasan kerja karyawan, meski caranya bervariasi dari satu 
Ni Kadek Yustina Novita Sari, Pengaruh Kepemimpinan Transformasional dan...

perusahaan dengan perusahaan lain, tergantung pada bidang usaha dari masingmasing perusahaan. Hal ini dilakukan dalam upaya untuk meningkatkan kepuasan karyawan yang berdampak terhadap produktivitas perusahaan (Chaisunah et al., 2010). Berdasarkan uraian latar belakang tersebut di atas maka dapat dirumuskan masalah penelitian yaitu : 1) Bagaimana pengaruh kepemimpinan transformasional terhadap kepuasan kerja pegawai pada Badan Pemberdayaan Masyarakat dan Pemdes Pemerintah Kota Denpasar? 2) Bagaimana pengaruh komitmen organisasional terhadap kepuasan kerja pegawai pada Badan Pemberdayaan Masyarakat dan Pemdes Pemerintah Kota Denpasar?

Bass dan Avolio (2003) menegaskan bahwa kepemimpinan transformasional merupakan salah satu faktor penentu kepuasan kerja, dimana kepemimpinan transformasional adalah gaya kepemimpinan dimana seorang pemimpin memfokuskan perhatiannya pada transaksi interpersonal antara pemimpin dengan bawahan yang melibatkan hubungan pertukaran. Perukaran tersebut didasarkan pada kesepakatan mengenai klasifikasi sasaran, standar kerja, penugasan kerja, dan penghargaan. Agusthina et al. (2012), mengungkapkan bahwa keluarnya karyawan lebih banyak disebabkan oleh ketidakpuasan terhadap kondisi kerja karena karyawan merasa pimpinan tidak memberi kepercayaan kepada karyawan, tidak ada keterlibatan karyawan terhadap pembuatan keputusan, pemimpin berlaku tidak objektif dan tidak jujur pada karyawan. Pendapat ini didukung oleh Rifki (2012) yang mengemukakan bahwa alasan utama karyawan meninggalkan perusahaan disebabkan karena pemimpin gagal memahami karyawan dan pemimpin tidak memperhatikan kebutuhan-kebutuhan karyawan.Yulinda (2013) 
dalam penelitiannya menunjukkan bahwa kendala yang menghambat perkembangan perusahaan adalah keterbatasan tenaga kerja yang terampil dan tingginya turnover yang disebabkan karena kepemimpinan yang kurang memotivasi, dukungan dan arahan kepada karyawan sehingga berdampak terhadap kepuasan kerja karyawan. Kepemimpinan transformasional berpengaruh signifikan terhadap kepuasan kerja (Atmojo, 2012). Bushra et al. (2011), Dewi (2013), dan Ritawati (2013) menyatakan bahwa kepemimpinan transformasional secara signifikan dan positif mempengaruhi kepuasan kerja. Dari pemahaman diatas dapat ditarik hipotesis sebagai berikut.

$\mathrm{H}_{1}$ : Kepemimpinan transformasional berpengaruh positif dan signifikan terhadap kepuasan kerja karyawan.

Teman (2005) dalam penelitiannya menyatakan secara teoritis komitmen organisasi merupakan salah satu faktor yang sangat penting bagi individu dalam bekerja untuk meningkatkan kepuasan kerja. Karyawan yang puas akan lebih dapat berbicara positif tentang organisasi, membantu orang lain, dan jauh melebihi harapan normal dari pekerjaan mereka. seseorang dengan tingkat komitmen organisasi tinggi menunjukkan sikap yang positif terhadap pekerjaannya. Bukti empiris yang dilakukan oleh Durrotun (2006) menyatakan bahwa tingkat komitmen berhubungan dengan kepuasan kerja, berimplikasi pada dugaan bahwa rendahnya kepuasan kerja saat ini tidak hanya disebabkan karena belum diikutsertaanya karyawan dalam pengambilan keputusan ataupun penerapan gaya kepemimpinan, namun juga dipicu oleh rendahnya komitmen karyawan. Apabila hal ini terjadi maka sulit bagi perusahaan untuk mewujudkan tujuan-tujuan yang telah ditetapkan, karena perusahaan tidak hanya membutuhkan seorang karyawan 
Ni Kadek Yustina Novita Sari, Pengaruh Kepemimpinan Transformasional dan...

yang pintar dan cedas tetapi juga bagaimana ia mempunyai sikap komitmen terhadap organisasi, karena tanpa itu semua akan sulit bagi perusahaan untuk dapat mencapai tujuannya. Penelitian yang dilakukan oleh Rohman (2009) menyatakan komitmen organisasional yaitu aspek komitmen affektive memiliki pengaruh positif yang signifikan terhadap kepuasan kerja. Rizwan et al. (2011) menyatakan dalam penelitiannya secara parsial kepuasan kerja dipengaruhi oleh komitmen organisasional. Dipertegas oleh Nadia (2011) dalam penelitiannya komitmen organisasional secara parsial berpengaruhi terhadap kepuasan kerja karyawan. Dari pemahaman diatas ditarik hipotesis sebagai berikut.

$\mathrm{H}_{2}$ : Komitmen organisasional berpengaruh positif dan signifikan terhadap kepuasan kerja karyawan.

Berdasarkan teori tersebut diusulkan kerangka konseptual penelitian yang ditunjukkan pada gambar 1

\section{Gambar 1. Kerangka Konseptual Penelitian}

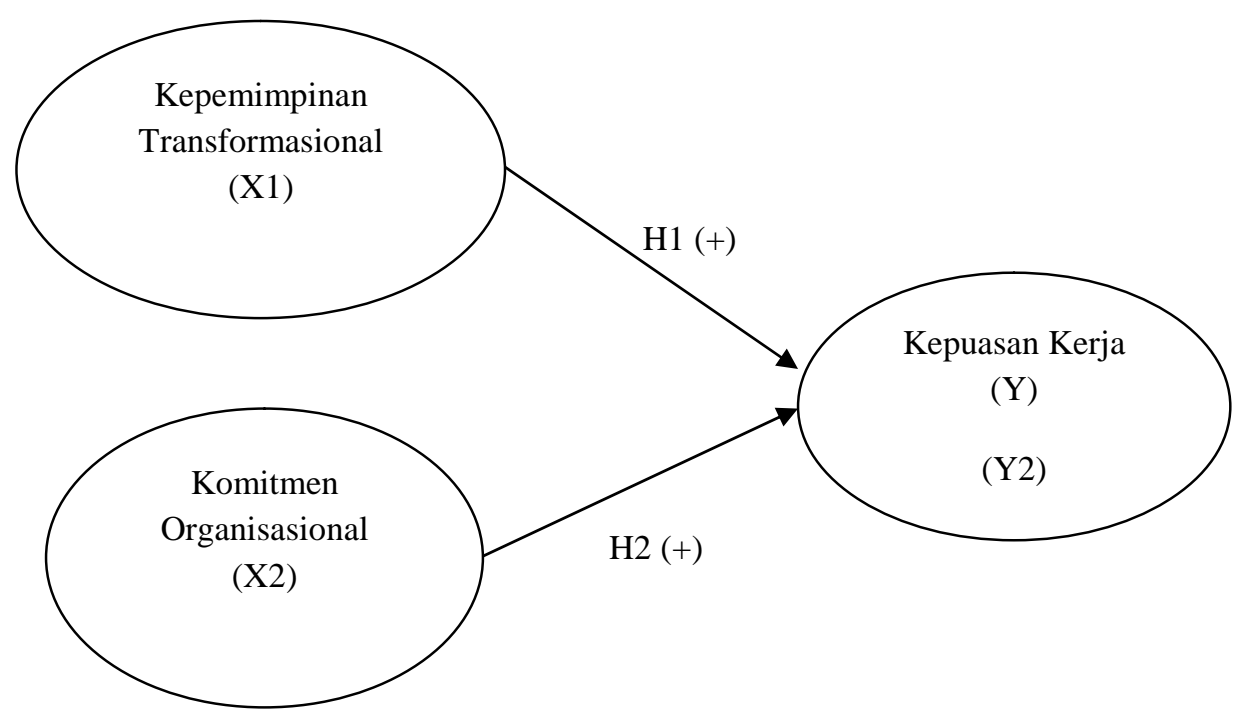




\section{METODE PENELITIAN}

Penelitian ini merupakan penelitian survei untuk menguji hubungan variabel kepemimpinan transformasional, variabel komitmen organisasional terhadap kepuasan kerja. Penelitian ini dilakukan di Badan Pemberdayaan Masyarakat dan Pemdes Pemerintah Kota Denpasar yang beralamat di J1. Hayam Wuruk No 69 Denpasar.

Subyek dalam penelitian ini adalah seluruh karyawan tetap laki-laki dan perempuan pada Badan Pemberdayaan Masyarakat dan Pemdes Pemerintah Kota Denpasar, untuk menguji hubungan kepemimpinan transformasional dan komitmen organisasional terhadap kepuasan kerja Badan Pembedayaan Masyarakat dan Pemdes Pemerintah Kota Denpasar.

Populasi adalah wilayah generalisasi yang terdiri atas objek atau subjek yang mempunyai kualitas dan karakteristik tertentu yang ditetapkan oleh peneliti untuk dipelajari dan kemudian ditarik kesimpulannya (Sugiyono, 2009:115). Populasi peneitian adalah seluruh pegawai Badan Pemberdayaan Masyarakat dan Pemdes Pemerintah Kota Denpasar yang berjumlah 34 orang. Penelitian ini menggunakan sampel jenuh, dimana seluruh populasi penelitian akan dipilih menjadi sampel (Sugiyono 2010:116).

Data variabel kepemimpinan transformasional akan diukur dengan idealized influence, inspirational motivation, intellectual stimulation and invidualized consideration yang dikembangkan oleh Khasawneh et al. (2012). Idealized influence, inspirational motivation, intellectual stimulation and invidualized consideration terdiri dari 20 item didalam mengukur 4 dimensi kepemimpinan 
Ni Kadek Yustina Novita Sari, Pengaruh Kepemimpinan Transformasional dan...

transformasional. Data diukur dengan skala likert dengan interval 1 sampai 5 yang mewakili interval sangat tidak setuju hungga sangat setuju. Indikator pengukuran data antara lain: memotivasi dan menginspirasi bawahan.

Data variabel komitmen organisasional akan diukur dengan affective. Continuance, and Normative Commitment Scale yang dikembangkan oleh Allen dan Meyer (1990). Affective, Continuance, and Normative Commitment Scale terdiri dari 23 item didalam mengukur 3 dimensi komitmen organisasional. Data diukur dengan skala likert dengan interval 1 sampai 5 yang mewakili interval sangat tidak setuju hingga sangat setuju. Indikator pengukuran data antara lain: setia dengan organisasi, dan keterikatan dengan organisasi.

Data variabel kepuasan kerja akan diukur dengan work itself, salary, supervisor support, work condition, dan rekan kerja yang dikembangkan oleh Scot dan Peter (1997). Work it self, pay, interpersonal relation, work condition, company policy and admonistration, job security, supervision technical, achievment, recognition, responsibility, posibility of growth, and advanceiment terdiri dari 25 item didalam mengukur 12 dimensi kepuasan kerja. Data diukur dengan skala likert dengan interval 1 sampai 5 yang mewakili interval sangat tidak setuju hingga sangat setuju. Indikator pengukuran data antara lain: imbalan yang sesuai harapan dan lingkungan kerja yang nyaman.

Penelitian ini memakai metode analisis regresi linier berganda yang nantinya berguna sebagai alat guna mencari tahu pengaruh variabel bebas dengan variabel terikat. Variabel bebas merupakan variabel yang mempengaruhi di dalam penelitian ini yaitu variabel kepemimpinan transformasional (X1) dan komitmen 
organisasional (X2), sedangkan variabel terikat merupakan variabel yang dipengaruhi di dalam peneitian ini adalah kepuasan kerja (Y).

Analisis regresi linier berganda merupakan persamaan regresi dengan menggunakan dua atau lebih variabel independen (Sugiyono, 2013:257). Persamaan regresi linier berganda yang digunakan dalam penelitian ini adalah sebagai berikut.

$$
Y=\alpha+\beta_{1} X_{1}+\beta_{2} X_{2}+e
$$

Keterangan:

$\mathrm{Y} \quad=$ Kepuasan kerja

$\mathrm{X} 1=$ Kepemimpinan transformasional

$\mathrm{X} 2=$ Komitmen organisasional

$\alpha \quad=$ Konstanta

$\beta_{1}, \beta_{2}=$ Koefisien masing-masing faktor

$\mathrm{e} \quad=$ Kesalahan atau standard error

\section{HASIL DAN PEMBAHASAN}

Badan Pemberdayaan Masyarakat dan Pemerintahan Desa Kota Denpasar adalah Lembaga Teknis Daerah yang merupakan unsur pendukung tugas Walikota dipimpin oleh seorang Kepala yang berkedudukan dibawah dan bertanggung jawab kepada Walikota melalui Sekretaris Daerah.

Karakteristik responden merupakan data responden yang dikumpulkan untuk mengetahui profil responden penelitian. Teknik pengambilan sampel dalam penelitian ini menggunakan sensus atau sampel jenuh, sehingga responden penelitian berjumlah 34 orang pegawai Badan Pemberdayaan Masyarakat dan Pemerintahan Desa Kota Denpasar. Responden penelitian digambarkan dengan menyajikan karakteristiknya berdasarkan variabel demografi yaitu jenis kelamin, 
usia, pendidikan terakhir, dan masa kerja seperti yang disajikan dalam Tabel 1 sebagai berikut.

\section{Tabel 1.}

Distribusi Karakteristik Responden

\begin{tabular}{|c|c|c|c|c|}
\hline No & Karakteristik & Klasifikasi & $\begin{array}{l}\text { Jumlah } \\
\text { Responden } \\
\text { (orang) }\end{array}$ & $\begin{array}{c}\text { Presentase } \\
\text { Responden } \\
(\%)\end{array}$ \\
\hline \multirow[t]{2}{*}{1} & \multirow[t]{2}{*}{ Jenis Kelamin } & Laki-Laki & 16 & 47,06 \\
\hline & & Perempuan & 18 & 52,94 \\
\hline \multicolumn{3}{|c|}{ Jumlah } & 34 & 100 \\
\hline \multirow[t]{3}{*}{2} & \multirow[t]{3}{*}{ Usia } & 20 - 30 Tahun & 17 & 50,00 \\
\hline & & $31-40$ Tahun & 12 & 35,29 \\
\hline & & $\geq 40$ Tahun & 5 & 14,71 \\
\hline \multicolumn{3}{|c|}{ Jumlah } & 34 & 100 \\
\hline \multirow[t]{4}{*}{3} & \multirow{4}{*}{$\begin{array}{c}\text { Tingkat } \\
\text { Pendidikan }\end{array}$} & SMA & 6 & 17,65 \\
\hline & & Diploma & 9 & 26,47 \\
\hline & & Sarjana & 16 & 47,06 \\
\hline & & Pascasarjana & 3 & 8,82 \\
\hline \multicolumn{3}{|c|}{ Jumlah } & 34 & 100 \\
\hline \multirow[t]{5}{*}{4} & \multirow[t]{5}{*}{ Masa Kerja } & $<5$ tahun & 9 & 26,47 \\
\hline & & 5-10 tahun & 12 & 35,29 \\
\hline & & 10-15 tahun & 7 & 20,59 \\
\hline & & $>15$ tahun & 6 & 17,65 \\
\hline & & Jumlah & 34 & 100 \\
\hline
\end{tabular}

Sumber : Hasil pengolahan data primer, 2017

Tabel 1 menunjukkan jumlah responden wanita sebanyak 18 orang $(52,94$ persen), dan responden pria sebanyak 16 orang (47,06 persen). Hal ini menunjukan bahwa pegawai Badan Pemberdayaan Masyarakat dan Pemerintahan Desa Kota Denpasar di dominasi oleh responden wanita. Data juga menunjukkan bahwa responden yang berusia 20-30 tahun adalah sebanyak 17 orang. Responden yang berusia 31-40 tahun adalah sebanyak 12 orang dan responden yang berusia lebih dari 40 tahun sebanyak 5 orang. Hal ini menunjukkan bahwa pegawai Badan Pemberdayaan Masyarakat dan Pemerintahan Desa Kota Denpasar dominan berusia 20-30 tahun yang merupakan kelompok usia produktif dengan persentase sebesar 50 persen. Faktor usia seorang pegawai dapat menunjang kegiatan 
organisasi dalam menghasilkan organisasi yang berkualitas. Karena dengan umur produktif yang dimiliki akan berkorelasi di dalam pencapaian tujuan organisasi tersebut.

Mayoritas pegawai di Badan Pemberdayaan Masyarakat dan Pemerintahan Desa Kota Denpasar adalah kelompok responden dengan tingkat pendidikan Sarjana sebesar 47,06 persen, sedangkan responden dengan tingkat pendidikan SMA, Diploma dan Pascasarjana masing-masing sebanyak 17,65 persen, 26,47 persen dan 8,82 persen. Informasi ini memberikan gambaran bahwa pegawai di Badan Pemberdayaan Masyarakat dan Pemerintahan Desa Kota Denpasar paling dominan adalah lulusan Sarjana yang dianggap sudah mampu serta memadai untuk menjadi pegawai pemerintahan yang memiliki kompetensi untuk mencapai tujuan organisasi.

Pengelompokkan responden berdasarkan masa kerja menunjukkan bahwa responden yang bekerja di Badan Pemberdayaan Masyarakat dan Pemerintahan Desa Kota Denpasar paling dominan adalah kurang dari 5-10 tahun yaitu dengan jumlah sebanyak 35,29 persen. Responden yang bekerja selama kurang dari 5 tahun sebanyak 26,47 persen. Responden yang bekerja selama 10 sampai 15 tahun sebanyak 20,59 persen, sedangkan yang bekerja lebih dari 15 tahun sebanyak 17,65 persen. Hal ini menunjukkan bahwa responden memiliki komitmen yang tinggi hingga mampu bertahan bekerja di Badan Pemberdayaan Masyarakat dan Pemerintahan Desa Kota Denpasar selama 5 sampai 10 tahun.

Sebuah instrumen dikatakan valid jika mampu mengukur apa yang seharusnya diukur, dan dapat mengungkap data dari variabel yang diteliti secara 
Ni Kadek Yustina Novita Sari, Pengaruh Kepemimpinan Transformasional dan...

tepat. Suatu instrument dikatakan valid jika korelasi antara skor faktor dengan skor total bernilai positif dan nilainya lebih dari $0,30(\mathrm{r}>0,3)$. Hasil uji validitas dalam penelitian ini menunjukkan bahwa seluruh variabel memiliki nilai koefisien korelasi dengan skor total seluruh item pernyataan lebih besar dari 0,30 . Hal ini menunjukkan bahwa butir-butir pernyataan dalam instrumen penelitian tersebut valid, sehingga layak digunakan untuk melakukan penelitian.

Suatu instrument dikatakan reliabel, jika instrument tersebut memiliki nilai Alpha Cronbach lebih dari 0,60. Adapun hasil dari uji reliabilitas dapat ditunjukkan pada tabel 2 berikut :

Tabel 2.

Hasil Uji Reliabilitas Variabel Penelitian

\begin{tabular}{llcc}
\hline No. & \multicolumn{1}{c}{ Variabel } & Cronbadh'sAlpha & Keterangan \\
\hline $\mathbf{1}$ & Kepemimpinan Transformasional (X1) & 0,760 & Reliabel \\
$\mathbf{2}$ & Komitmen Organisasional (X2) & 0,758 & Reliabel \\
$\mathbf{3}$ & Kepuasan Kerja (Y) & 0,755 & Reliabel \\
\hline \multicolumn{2}{l}{ Sumber $:$ Hasil pengolahan data primer, 2017 }
\end{tabular}

Hasil uji reliabilitas yang disajikan dalam Tabel 2 menunjukkan bahwa ketiga instrumen penelitian yaitu kepemimpinan transformasional, komitmen organisasional dan kepuasan kerja memiliki koefisien Cronbach's Alpha lebih dari 0,60. Hal ini dapat dikatakan bahwa semua instrumen reliabel sehingga dapat digunakan untuk melakukan penelitian.

Hasil analisis faktor konfirmatori dari variabel kepemimpinan transformasional, komitmen organisasional dan kepuasan kerja menunjukkan semua indikator konstruk tersebut mempunyai loading faktor dengan nilai diatas 0,5. Maka dapat disimpulkan bahwa semua variabel memiliki loading factor di atas 0,50 atau faktor loading yang tinggi. Dengan hasil ini, maka dapat dikatakan indikator-indikator pembentuk variabel kepemimpinan transformasional, 
komitmen organisasional dan kepuasan kerja telah menunjukkan sebagai indikator yang kuat. Selanjutnya berdasarkan analisis faktor konfirmatori ini, maka model penelitian dapat digunakan untuk analisis selanjutnya tanpa dimodifikasi atau penyesuaian-penyesuaian.

Data yang diperoleh dari penyebaran instrumen penelitian perlu dideskripsikan untuk memberikan suatu interpretasi yang jelas pada data yang diperoleh melalui proses penelitian tersebut. Hasil analisis deksriptif yang diperoleh dalam penelitian ini menunjukkan skor rata-rata kepemimpinan transformasional sebesar 3,95, yang berarti bahwa tingkat kepemimpinan transformasional pada Badan Pemberdayaan Masyarakat dan Pemerintahan Desa Kota Denpasar dikatakan baik. Pencapaian nilai rata-rata diikuti oleh adanya indikator yang lebih tinggi dan lebih rendah dari rata-rata variabel kepemimpinan transformasional. Dari 20 pernyataan yang digunakan untuk mengukur kepemimpinan transformasional, maka terdapat 10 pernyataan yang nilainya berada di atas nilai rata-rata $(3,95)$ variabel kepemimpinan transformasional. Hal tersebut disebabkan karena pimpinan Badan Pemberdayaan Masyarakat dan Pemerintahan Desa Kota Denpasar mampu membuat pegawai senang bila berada disekitarnya, mampu memberikan perhatian secara pribadi kepada pegawai yang kelihatan terabaikan, mampu membuat pegawai merasa nyaman saat berdiskusi dalam setiap permasalahan, membuat pegawai bangga bergaul dengannya, mampu mengakui prestasi pegawai, mampu memberikan inspirasi pada pegawai cara-cara dalam melihat masalah-masalah yang mulanya sangat sulit bagi pegawai, mampu memberi tahu pegawai bagaimana cara mengerjakan pekerjaan, mengetahui apa 
Ni Kadek Yustina Novita Sari, Pengaruh Kepemimpinan Transformasional dan...

yang bawahan inginkan dan menolong pegawai untuk mendapatkannya, serta memuji pegawai jika pegawai melakukan pekerjaan dengan baik, sehingga pimpinan menjadi seseorang yang sangat di percayai oleh pegawai Badan Pemberdayaan Masyarakat dan Pemerintahan Desa Kota Denpasar.

Pernyataan lain sudah memperoleh penilaian yang baik dari pegawai berdasarkan hasil kuisioner, namun masih lebih rendah dari nilai rata-rata variabel kepemipinan transformasional. Dalam upaya meningkatkan kepemimpinan transformasional ke arah yang lebih baik, maka pimpinan diharapkan dapat mendorong pegawai untuk lebih kreatif, memberikan perhatian dan semangat atas pekerjaan pegawai, serta mengungkapkan tujuan-tujuan dan manfaat-manfaat yang penting bagi pegawai dengan cara yang lebih sederhana.

Hasil analisis deksriptif menunjukkan skor rata-rata komitmen organisasional sebesar 4,08, yang berarti bahwa pegawai Badan Pemberdayaan Masyarakat dan Pemerintahan Desa Kota Denpasar sudah memiliki komitmen organisasional yang baik. Pencapaian nilai rata-rata tersebut diikuti oleh adanya indikator yang lebih tinggi dan lebih rendah dari rata-rata variabel komitmen organisasional. Dari 23 pernyataan yang digunakan untuk mengukur komitmen organisasional, maka terdapat 9 pernyataan yang nilainya berada di atas nilai ratarata $(4,08)$ variabel komitmen organisasional. Komitmen organisasional yang tinggi pada pegawai Badan Pemberdayaan Masyarakat dan Pemerintahan Desa Kota Denpasar disebabkan karena pegawai memiliki perasaan senang menghabiskan masa produktif di organisasi ini. Selain itu pegawai juga memiliki sikap komitmen yang tinggi yang ditunjukkan dengan sikap seperti : bangga 
bercerita tentang perusahaan, pegawai menganggap masalah organisasi merupakan masalah pegawai juga, setiap saat pegawai memikirkan kondisi organisasi, kehancuran perusahaan berhubungan dengan harga diri pegawai, meninggalkan organisasi ini menimbulkan kerugian material, kesetiaan pada perusahaan bermanfaat bagi karyawan karena kapitalisasi masa bakti, kesetiaan adalah sikap yang harus dimiliki karyawan setiap perusahaan, dan karyawan diwajibkan setia pada satu perusahaan, sehingga pegawai Badan Pemberdayaan Masyarakat dan Pemerintahan Desa Kota Denpasar cenderung memiliki komitmen yang tinggi.

Pernyataan lain dalam penelitian ini sudah memperoleh penilaian yang baik dari pegawai berdasarkan hasil kuisioner, namun masih lebih rendah dari nilai rata-rata variabel komitmen organisasional. Dalam upaya meningkatkan komitmen organisasional ke arah yang lebih baik, maka pegawai diharapkan menyadari bahwa tetap bekerja dalam organisasi ini merupakan kewajiban moral.

Hasil analisis deksriptif menunjukkan skor rata-rata kepuasan kerja sebesar 4,05, yang berarti bahwa pegawai Badan Pemberdayaan Masyarakat dan Pemerintahan Desa Kota Denpasar sudah memiliki kepuasan kerja yang baik. Pencapaian nilai rata-rata tersebut diikuti oleh adanya indikator yang lebih tinggi dan lebih rendah dari rata-rata variabel kepuasan kerja. Dari 25 pernyataan yang digunakan untuk mengukur kepuasan kerja, maka terdapat 13 pernyataan yang nilainya berada di atas nilai rata-rata $(4,05)$ variabel kepuasan kerja. Kepuasan kerja yang tinggi pada pegawai Badan Pemberdayaan Masyarakat dan Pemerintahan Desa Kota Denpasar disebabkan karena pegawai memiliki perasaan 
Ni Kadek Yustina Novita Sari, Pengaruh Kepemimpinan Transformasional dan...

bangga bekerja di organisasi yang mampu menghargai apa yang telah mereka capai. Selain itu pegawai juga merasa puas terhadap pekerjaan mereka karena memberikan mereka perasaan puas telah mampu menyelesaikan pekerjaan dengan baik dan pimpinan selalu berterima kasih terhadap pekerjaan yang telah selesai mereka lakukan. Pegawai Badan Pemberdayaan Masyarakat dan Pemerintahan Desa Kota Denpasar juga merasa dihargai saat berhasil menyelesaikan suatu tugas, bangga bekerja di organisasi ini karena mereka dapat berkembang sebagai seorang individu, dan merasa puas terhadap gaji yang diterima, karena pegawai merasa gajinya lebih tinggi dibandingkan dengan gaji rekan kerja yang melakukan pekerjaan serupa dengan mereka.

Pernyataan lain dalam penelitian ini sudah memperoleh penilaian yang baik dari pegawai berdasarkan hasil kuisioner, namun masih lebih rendah dari nilai rata-rata variabel kepuasan kerja. Dalam upaya meningkatkan kepuasan kerja ke arah yang lebih baik, maka pegawai diharapkan menyadari bahwa rekan kerja merupakan salah satu hal penting dalam bekerja disuatu organisasi, sehingga pegawai dapat bekerjasama dengan baik, dan menyelesaikan pekerjaan bersama, agar tugas menjadi lebih ringan dan dapat diselesaikan dengan cepat.

Uji asumsi klasik dilakukan dengan tujuan untuk memastikan hasil yang diperoleh memenuhi asumsi dasar di dalam analisis regresi. Hasil uji asumsi klasik yang dilakukan dalam penelitian ini adalah uji normalitas, uji multikoliniearitas, dan uji heteroskedastisitas. Hasil dari uji asumsi klasik yang diolah dengan bantuan software SPSS 18.0 disajikan sebagai berikut: 
Uji normalitas bertujuan untuk mengetahui apakah residual dari model regresi yang dibuat berdistribusi normal atau tidak. Untuk menguji apakah data yang digunakan normal atau tidak dapat dilakukan dengan menggunakan uji Kolmogorov Sminarnov. Apabila koefisien Asymp. Sig. (2-tailed) lebih besar dari 0,05 maka data tersebut dikatakan berdistribusi normal.

Tabel 3.

Hasil Uji Normalitas

\begin{tabular}{cc}
\hline & Unstandardized Residual \\
\hline $\mathbf{N}$ & 34 \\
Kolmogorov-Smirnov $\boldsymbol{Z}$ & 0,555 \\
Asymp.Sig.(2-tailed) & 0,918 \\
\hline
\end{tabular}

Sumber: Hasil pengolahan data primer, 2017

Berdasarkan Tabel 3 dapat dilihat bahwa nilai Kolmogorov Sminarnov (KS) sebesar 0,555, sedangkan nilai Asymp. Sig. (2-tailed) sebesar 0,918. Hasil tersebut mengindikasikan bahwa model persamaan regresi tersebut berdistribusi normal karena nilai Asymp. Sig. (2-tailed) 0,555 lebih besar dari nilai alpha 0,05.

Uji multikolinieritas bertujuan untuk menguji apakah pada model regresi ditemukan adanya korelasi antar variabel bebas. Adanya multikolinearitas dapat dilihat dari nilai tolerance atau variance inflation factor (VIF). Jika nilai tolerance lebih dari $10 \%$ atau VIF Kurang dari 10, maka dikatakan tidak ada multikolinearitas.

Tabel 4.

Hasil Uji Multikoleniaritas

\begin{tabular}{lcc}
\hline \multicolumn{1}{c}{ Variabel } & Tolerance & VIF \\
\hline Kepemimpinan transformasional $\left(\mathbf{X}_{1}\right)$ & 0,591 & 1,691 \\
Komitmen organisasional $\left(\mathbf{X}_{2}\right)$ & 0,591 & 1,691 \\
\hline Sumber: Hasil pengolahan data primer, 2017 & &
\end{tabular}

Berdasarkan Tabel 4 dapat dilihat bahwa nilai tolerance dan VIF dari seluruh variable menunjukkan bahwa nilai tolerance untuk setiap variabel lebih 
Ni Kadek Yustina Novita Sari, Pengaruh Kepemimpinan Transformasional dan...

besar dari $10 \%$ dan nilai VIF lebih kecil dari 10 yang berarti model persamaan regresi bebas dari multikolinearitas.

Uji heteroskedastisitas bertujuan untuk mengetahui apakah dalam model regresi terjadi ketidaksamaan varians dari residual satu pengamatan ke pengamatan lain yang dilakukan dengan uji Glejser. Jika tidak ada satu pun variabel bebas yang berpengaruh signifikan terhadap nilai absolute residual atau nilai signifikansinya di atas 0,05 maka tidak mengandung gejala heteroskedastisitas.

Tabel 5.

Hasil Uji Heteroskedastisitas

\begin{tabular}{|c|c|c|c|c|c|c|}
\hline \multicolumn{2}{|c|}{ Model } & \multicolumn{2}{|c|}{$\begin{array}{l}\text { Unstandardized } \\
\text { Coefficients }\end{array}$} & \multirow{2}{*}{$\begin{array}{c}\text { Standardized } \\
\text { Coefficients } \\
\text { Beta }\end{array}$} & \multirow[t]{2}{*}{$\mathrm{t}$} & \multirow[t]{2}{*}{ Sig. } \\
\hline & & $\mathrm{B}$ & Std. Error & & & \\
\hline \multirow[t]{3}{*}{1} & (Constant) & 7.668 & 7.159 & & 1.071 & .292 \\
\hline & $\begin{array}{l}\text { Kepemimpinan } \\
\text { Transformasional }\end{array}$ & .012 & .086 & .033 & .143 & .887 \\
\hline & Komitmen Organisasi & -.052 & .098 & -.124 & -.534 & .597 \\
\hline
\end{tabular}

Sumber: Hasil pengolahan data primer, 2017

Pada Tabel 5 dapat dilihat bahwa nilai signifikansi dari variabel kepemimpinan transformasional, dan komitmen organisasional, masing-masing sebesar 0,887 dan 0,597. Nilai tersebut lebih besar dari 0,05 yang berarti tidak terdapat pengaruh antara variabel bebas terhadap absolute residual. Dengan demikian, model yang dibuat tidak mengandung gejala heteroskedastisitas.

Pengujian data dalam penelitian ini menggunakan teknik analisis regresi linier berganda. Perhitungan koefisien regresi linier berganda dilakukan dengan analisis regresi melalui software SPSS 18.0 for Windows, diperoleh hasil yang ditunjukan pada Tabel 6 berikut. 
Tabel 6.

\begin{tabular}{lcccc}
\multicolumn{1}{c}{ Variabel } & Hasil Analisis Regresi Linier Berganda & \\
& $\begin{array}{l}\text { Koefisien } \\
\text { Regresi }\end{array}$ & Std. Error & Nilai t & $\begin{array}{c}\text { Nilai } \\
\text { Signifikansi }\end{array}$ \\
\hline Constant & 24,444 & 11,584 & 2,110 & 0,043 \\
Kepemimpinan & 0,512 & 0,139 & 3,688 & 0,001 \\
Transformasional & & & & \\
Komitmen Organisasi & 0,387 & 0,159 & 2,437 & 0,021 \\
R Square & & & & 0,629 \\
F Hitung & & & & 26,248 \\
Signifikansi F & & & & 0,000 \\
\hline
\end{tabular}

Sumber : Hasil pengolahan data primer, 2017

Berdasarkan hasil analisis regresi linier berganda seperti yang disajikan pada Tabel 6, maka persamaan strukturalnya adalah sebagai berikut :

$$
\mathrm{Y}=24,444+0,512 \mathrm{X} 1+0,387 \mathrm{X} 2+\mathrm{e}
$$

Nilai koefisien regresi masing-masing variabel bebas bernilai positif dengan nilai signifikansi uji t kurang dari 0,05 . Hal ini menunjukkan bahwa variabel kepemimpinan transformasional dan komitmen organisasional memiliki pengaruh positif yang signifikan terhadap variabel kepuasan kerja. Besarnya pengaruh variabel bebas terhadap variabel terikat yang ditunjukkan oleh nilai determinasi total ( $\mathrm{R}$ Square) sebesar 0,629 mempunyai arti bahwa sebesar 62,9\% variasi kepuasan kerja dipengaruhi oleh variasi kepemimpinan transformasional dan komitmen organisasional Pegawai Badan Pemberdayaan Masyarakat dan Pemerintahan Desa Kota Denpasar, sedangkan sisanya sebesar 37,1\% djelaskan oleh faktor lain yang tidak dimasukkan ke dalam model.

Hasil uji simultan dalam penelitian ini diperoleh Nilai $F_{\text {hitung }}>F_{\text {tabel, }}$ 26,248 $>$ 2,91, dengan nilai sig. $0,000<0,05$, maka Ho ditolak dan $\mathrm{H}_{1}$ diterima. Kesimpulannya, pada kelompok yang diuji memiliki perbedaan yang nyata (signifikan). Hasil ini mempunyai arti bahwa ada pengaruh signifikan antara 
Ni Kadek Yustina Novita Sari, Pengaruh Kepemimpinan Transformasional dan...

kepemimpinan transformasional dan komitmen organisasional secara simultan terhadap kepuasan kerja pegawai Badan Pemberdayaan Masyarakat dan Pemerintahan Desa Kota Denpasar.

Hasil analisis menunjukkan bahwa kepemimpinan transformasional berpengaruh positif dan signifikan terhadap Kepuasan kerja pegawai. Hal ini memiliki makna bahwa semakin baik intensitas penerapan kepemimpinan transformasional pimpinan Badan Pemberdayaan Masyarakat dan Pemerintahan Desa Kota Denpasar, maka akan semakin tinggi pula kepuasan kerja yang ditunjukkan pegawai. Begitu pula sebaliknya, semakin buruk intensitas penerapan kepemimpinan transformasional pimpinan Badan Pemberdayaan Masyarakat dan Pemerintahan Desa Kota Denpasar maka semakin rendah tingkat kepuasan kerja pegawai pada organisasi tersebut.

Hasil tersebut mengindikasikan bahwa nilai - nilai yang terkandung dalam gaya kepemimpinan transformasional mampu dipersepsikan dengan baik dan berdampak nyata terhadap kepuasan kerja pegawai Badan Pemberdayaan Masyarakat dan Pemerintahan Desa Kota Denpasar. Perilaku pemimpin yang mampu membuat pegawai senang bila berada disekitarnya, mampu memberikan perhatian secara pribadi kepada pegawai yang kelihatan terabaikan, mampu membuat pegawai merasa nyaman saat berdiskusi dalam setiap permasalahan, membuat pegawai bangga bergaul dengannya, mampu mengakui prestasi pegawai, mampu memberikan inspirasi pada pegawai cara-cara dalam melihat masalah-masalah yang mulanya sangat sulit bagi pegawai, mampu memberi tahu pegawai bagaimana cara mengerjakan pekerjaan, mengetahui apa yang bawahan 
inginkan dan menolong pegawai untuk mendapatkannya, serta memuji pegawai jika pegawai melakukan pekerjaan dengan baik, maka akan dapat meningkatkan perilaku kepuasan kerja pegawai pada Badan Pemberdayaan Masyarakat dan Pemerintahan Desa Kota Denpasar.

Kepemimpinan transformasional yang diukur berdasarkan indikator: idealized influence, inspiration motivation, intellectual stimulation, dan individualized consideration, terbukti mampu meningkatkan Kepuasan kerja pegawai Badan Pemberdayaan Masyarakat dan Pemerintahan Desa Kota Denpasar. Temuan ini dapat diartikan bahwa apabila intensitas penerapan kepemimpinan transformasional oleh pimpinan Badan Pemberdayaan Masyarakat dan Pemerintahan Desa Kota Denpasar ditingkatkan, maka akan mampu memberikan kontribusi yang signifikan untuk meningkatkan kepuasan kerja pegawai Badan Pemberdayaan Masyarakat dan Pemerintahan Desa Kota Denpasar. Penelitian ini mendukung beberapa hasil penelitian sebelumnya dan konsisten dengan hasil penelitian Bass dan Avolio (2003), Agusthina et al. (2012), (Atmojo, 2012). Bushra et all. (2011), Dewi (2013), dan Ritawati (2013), yang menunjukkan bahwa, terdapat hubungan yang positif dan signifikan antara kepemimpinan transformasional terhadap kepuasan kerja pegawai.

Hasil analisis menunjukkan bahwa komitmen organisasional berpengaruh positif dan signifikan terhadap kepuasan kerja pegawai. Hal ini memiliki makna bahwa semakin tinggi komitmen organisasional pegawai Badan Pemberdayaan Masyarakat dan Pemerintahan Desa Kota Denpasar, maka akan semakin tinggi pula kepuasan kerja yang ditunjukkan pegawai. Begitu pula sebaliknya, semakin 
Ni Kadek Yustina Novita Sari, Pengaruh Kepemimpinan Transformasional dan...

rendah komitmen organisasional pegawai Badan Pemberdayaan Masyarakat dan Pemerintahan Desa Kota Denpasar maka semakin rendah tingkat kepuasan kerja pegawai pada organisasi tersebut.

Hasil tersebut mengindikasikan bahwa nilai - nilai yang terkandung dalam komitmen organisasional mampu dipersepsikan dengan baik dan berdampak nyata terhadap kepuasan kerja pegawai Badan Pemberdayaan Masyarakat dan Pemerintahan Desa Kota Denpasar. Perilaku pegawai yang mampu memiliki perasaan senang menghabiskan masa produktif di organisasi ini. Selain itu pegawai yang memiliki sikap komitmen yang tinggi yang ditunjukkan dengan sikap seperti : bangga bercerita tentang perusahaan, pegawai menganggap masalah organisasi merupakan masalah pegawai juga, setiap saat pegawai memikirkan kondisi organisasi, kehancuran perusahaan berhubungan dengan harga diri pegawai, meninggalkan organisasi ini menimbulkan kerugian material, kesetiaan pada perusahaan bermanfaat bagi karyawan karena kapitalisasi masa bakti, kesetiaan adalah sikap yang harus dimiliki karyawan setiap perusahaan, dan karyawan diwajibkan setia pada satu perusahaan, maka akan dapat meningkatkan perilaku kepuasan kerja pegawai pada Badan Pemberdayaan Masyarakat dan Pemerintahan Desa Kota Denpasar.

Komitmen organisasional yang diukur berdasarkan indikator: komitmen afektif, komitmen berkelanjutan dan komitmen normatif, terbukti mampu meningkatkan kepuasan kerja pegawai Badan Pemberdayaan Masyarakat dan Pemerintahan Desa Kota Denpasar. Temuan ini dapat diartikan bahwa apabila intensitas penerapan komitmen organisasional oleh pegawai Badan Pemberdayaan 
Masyarakat dan Pemerintahan Desa Kota Denpasar ditingkatkan, maka akan mampu memberikan kontribusi yang signifikan untuk meningkatkan kepuasan kerja pegawai Badan Pemberdayaan Masyarakat dan Pemerintahan Desa Kota Denpasar.

Penelitian ini mendukung beberapa hasil penelitian sebelumnya dan konsisten dengan hasil penelitian Teman (2005), Durrotun (2006), Rohman (2009), Rizwan et al. (2011), dan Nadia (2011) yang menunjukkan bahwa, terdapat hubungan yang positif dan signifikan antara komitmen organisasional terhadap kepuasan kerja pegawai.

\section{SIMPULAN DAN SARAN}

Simpulan yang dapat diambil berdasarkan hasil penelitian dan pembahasan pada bab sebelumnya yaitu kepemimpinan transformasional berpengaruh positif dan signifikan terhadap kepuasan kerja pegawai. Hal ini berarti bahwa semakin baik penerapan nilai-nilai kepemimpinan transformasional oleh pimpinan Badan Pemberdayaan Masyarakat dan Pemerintahan Desa Kota Denpasar, maka akan semakin tinggi pula kepuasan kerja pegawai yang ditunjukkan pegawainya.

Komitmen organisasional berpengaruh positif dan signifikan terhadap kepuasan kerja pegawai. Hal ini berarti bahwa semakin tinggi komitmen organisasional pegawai Badan Pemberdayaan Masyarakat dan Pemerintahan Desa Kota Denpasar, maka akan semakin tinggi pula kepuasan kerja yang ditunjukkan pegawai tersebut.

Saran yang dapat diberikan berdasarkan hasil penelitian yaitu pemimpin disarankan mampu mendorong pegawai untuk lebih kreatif, memberikan perhatian 
Ni Kadek Yustina Novita Sari, Pengaruh Kepemimpinan Transformasional dan...

dan semangat atas pekerjaan pegawai, serta mengungkapkan tujuan-tujuan dan manfaat-manfaat yang penting bagi pegawai dengan cara yang lebih sederhana, agar dapat meningkatkan kepemimpinan transformasional pada Badan Pemberdayaan Masyarakat dan Pemerintahan Desa Kota Denpasar. Selain itu, sebaiknya pemimpin mendengarkan pendapat pegawai sebelum membuat keputusan terkait pekerjaan, sehingga kepuasan kerja pegawai pada Badan Pemberdayaan Masyarakat dan Pemerintahan Desa Kota Denpasar akan tercipta dengan sangat baik.

Pegawai disarankan agar bersedia menyadari bahwa tetap bekerja dalam organisasi ini merupakan kewajiban moral. Pegawai diharapkan menyadari bahwa rekan kerja merupakan salah satu hal penting dalam bekerja disuatu organisasi, sehingga pegawai dapat bekerjasama dengan baik, dan menyelesaikan pekerjaan bersama-sama, agar tugas menjadi lebih ringan dan dapat diselesaikan dengan cepat, sehingga dapat meningkatkan kepuasan kerja pegawai pada Badan Pemberdayaan Masyarakat dan Pemerintahan Desa Kota Denpasar.

\section{REFERENSI}

Atmojo, Marnis. 2012. The Influence of Transformational Leadership on Job Satisfaction, Organizational Commitment, and Employee Performance. International Research Journal of Business Studies, 5(2), pp: 113-128

Bushra, Fatima, Ahmad Usman, and Asvir Naveed. 2011. Effect of Transformational Leadership on Employees' Job Satisfaction and Organizational Commitment in Banking Sector of Lahore (Pakistan). International Journal of Business and Social Science, 2(8), pp: 261-267

Dewi, Kadek Shinta. 2013. Pengaruh Gaya Kepemimpinan Transformasional Terhadap Kepuasan Kerja Karyawan dan Komitmen Organisasi pada PT. KPM. Jurnal Manajemen, Strategi Bisnis, dan Kewirausahaan, 7(2), h: $116-125$ 
Erkutlu, Hakan. 2008. The Impact of Transformational Leadership on Organizational and Leadership Effectiveness The Turkish Case. Journal of Management Development, 27(7), pp: 708-726

Farahani, Majid, Marzieh Taghadosi, and Mehdi Behboudi. 2011. An Exploration of the Relationship between Transformational Leadership and Organizational Commitment: The Moderating Effect of Emotional Inteligence: Case Study in Iran. International Business Research, 4(4), pp: 211-217

Han, Tzu-Shian, Hsu-Hsin Chiang and Aihwa Chang. 2010. Employee participation in decision making, psychological ownership and knowledge sharing: mediating role of organizational commitment in Taiwanese hightech organizations. The International Journal of Human Resource Management, 21(12) pp: 2218-2233

Khan, Zunnoorain, Shahzad Khan, and Saqib Shahzad. 2013. Moderating Role of Procedural Justice and Empowerment in Transformational Leadership with is impact on Organizational Commitment. International Review of Management and Business Research, 2(3), pp: 847-852

Purnomo, Heru dan Muhammad Cholil. 2010. Pengarug Gaya Kepemimpinan Terhadap Kepuasan Kerja Berdasarkan Motivasi Kerja pada Karyawan Administratif di Universitas Sebelas Maret Surakarta. Jurnal Manajemen Sumberdaya Manusia, 4(1), h: 27-35

Rohman, Abdul. 2009. Pengaruh Komitmen Organisasional Terhadap Kepuasan Kerja Dan Keinginan Berpindah (Studi Pada Karyawan Kantor Akuntan Publik Di Jawa Tengah). Jurnal Akuntansi FE Unsil.Vol.4.No.1.

Riduwan, dan Engkos Achmad Kuncoro. 2012. Cara Menggunakan dan Memakai Path Analysis (Analysis Jalur). Bandung: Alfabeta

Ritawati, Agustina. 2013. Pengaruh Kepemimpinan Transformasional dan Budaya Organisasi Terhadap Kepuasan Kerja dan Kinerja Karyawan PT. Jamsostek (Persero) Cabang Surabaya. DIE: Jurnal Ilmu Ekonomi \& Manajemen, 9(1), h: 82-93

Sugiyono. 2013. Statistika Untuk Penelitian. Bandung: Alfabeta.

Sugiyono. 2013. Metode Penelitian Pendidikan (Pendekatan Kuantitatif, Kualitatif, dan R\&D).Bandung : Alfabeta.

Tranggono, Rahadyan \& Andika Kartika.2008.Pengaruh Komitmen Organisasional Dan Profesional Terhadap Kepuasan Kerja Auditor Dengan Motivasi Sebagai Variabel Intervening (Studi Empiris pada 
Ni Kadek Yustina Novita Sari, Pengaruh Kepemimpinan Transformasional dan...

Kantor Akuntan Publik di Semarang).Jurnal Bisnis dan Ekonomi.Vol.15, No.1.

Thamrin, H. M. 2012. The Influnce of Transformational Leadership and Organizational Commitment on Job Satisfaction and Employee Performance. International Journal of Innovation, Management and Technology, 3(5), pp: 566-572

Thoyib, Armanu, Noermijati, dan Siska Kristin Sugianto. 2012. Pengaruh PersonOrganization Fit (P-O Fit), Motivasi Kerja, dan Kepuasan Kerja terhadap Komitmen Pegawai. Jurnal Aplikasi Manajemen, 10(2), h: 229-238

Voon, M. L., M. C. Lo, K.S. Ngui, and N.B. Ayob. 2011. The Influence of Leadership Style on Employees Job Satisfaction in Public Sector Organizations in Malaysia. International Journal of Business, Management and Social Sciences, 2(1), pp: 24-32 